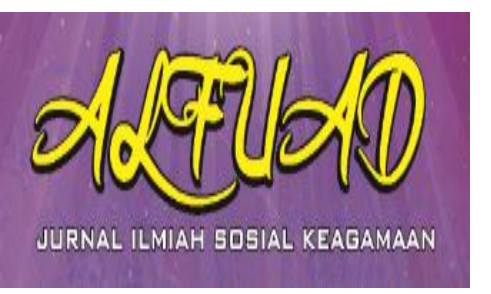

ALFUAD JOURNAL, 2 (2), 2018, (83-91)

(Print ISSN 2614-4786)

Available Online at

http://ecampus.iainbatusangkar.ac.id/ojs/index.php/alfuad

\title{
PENGARUH KONSELING ISLAM DALAM MENINGKATKAN KESADARAN SHOLAT BERJAMAAH SISWA
}

\section{Widia Wati \\ Indonesia \\ E-mail: widiawatynur@gmail.com}

\section{Silvianetri*)}

Institut Agama Islam Negeri Batusangkar Indonesia

E-mail: silvianetri.71@gmail.com

*) Corresponding Author

\begin{abstract}
The fundamental religious problems experienced by students today are the low awareness of prayers in congregation. One technique that can be used to increase awareness is to do the prayers in congregation through Islamic counseling. To reveal this in this study using the experimental method, specifically one group pretest-posttes. The research sample consisted of 25 students from SMAN 1 Pasaman. The instrument used was the student prayer awareness scale and data analysis using the t-test. The results revealed that: (1) there was an increase in students' awareness of prayers in congregation after being given a classical format Islamic counseling treatment with an average pretest of 46.04 points, which was in the low category, and posttest 58.76 points, in the high category, and a difference of 12.72 points , (2) there is the influence of Islamic counseling on increasing awareness of student prayer in congregation. Based on the results of this study it is recommended for counselors in schools to be able to apply Islamic counseling as a treatment for increasing student prayer awareness.
\end{abstract}

Keywords: Islamic Counseling, Awareness, Prayer Jamaah.

\section{PENDAHULUAN}

Institusi pendidikan merupakan sebuah wadah bagi siswa untuk menanamkan kesadaran beragama. Stark (Ebaugh, 2006) menyatakan bahwa institusi pendidikan merupakan lembaga untuk meningkatkan kesadaran beragama dan kultur sosial siswa yang nantinya akan meningkatkan kontrol diri siswa tersebut. Siswa yang mempunyai kontrol diri kuat akan mempunyai kesadaran beragama yang tinggi.
Selain institusi pendidikan, keluarga merupakan lembaga yang sangat besar perannya dalam membentuk keyakinan beragama anak. Arifin (2008: 55), mengatakan bahwa fungsi dan peran orang tua mampu membentuk arah keyakinan anak mereka. Orang tua memiliki peran penting dalam penanaman nilai-nilai tauhid terhadap anaknya. Hal tersebut seperti yang diungkapkan oleh Nabi Muhammad SAW yaitu "setiap anak yang lahir adalah dalam keadaan fitrah, maka kedua orangtua mereka 
yang akan menjadikannya Yahudi atau Nasrani (HR. Bukhari). Usaha penentuan arah pendidikan menjadi peran penentu adalah ayah dan ibunya.

Proses pendidikan perlu sinergi dari berbagai pihak, karena setiap bayi yang lahir itu memiliki potensi beragama, jadi pendidikan dari orangtuanya lah yang menentukan keyakinan seperti apa yang akan dianut sang anak nantinya. Pendidikan tidak hanya didapatkan dari orang tua saja melainkan juga dari proses pendidikan di sekolah, masyarakat dan teman sebayanya. Pendidikan yang di berikan sekolah kepada siswa tidak hanya berupa pendidikan umum, namun juga pendidikan agama. Materi pendidikan agama terkait dengan cara menghormati orang tua, guru, dan cara menghargai teman, dan cara beribadah. Sehingga siswa tidak hanya pintar dalam segi pengetahuan umum, namun juga pengetahuan agamanya. Arifin (2008: 57) menyatakan bahwa pendidikan agama di lembaga pendidikan akan memberikan pengaruh dalam pembentukan jiwa keagamaan pada anak. Namun demikian, besar kecilnya pengaruh tersebut sangat bergantung pada berbagai faktor yang dapat memotivasi anak untuk memahami nilai-nilai agama. Pendidikan agama pada hakikatnya lebih menitikberatkan pada bagaimana membentuk kebiasaan yang selaras dengan tuntutan agama.
Berdasarkan pendapat di atas dapat kita ketahui bahwa pendidikan agama pada institusi pendidikan akan mempengaruhi pembentukan jiwa keagamaan siswa, seberapa besar pengaruhnya tergantung pada motivasi siswa, oleh karena itu pendidik seharusnya menumbuhkan motivasi tersebut. Siswa akan meyakini atas apa yang ia peroleh dari proses pendidikan jika memiliki motivasi.

Ketika anak mulai beranjak remaja dan menuju dewasa, mereka mengalami suatu transisi yang besar yaitu masa mencari jati diri. Sarlito (2010: 72) mengatakan bahwa dalam rangka usaha mencari identitas diri, seorang remaja sering membantah orang tua karena ia mulai memiliki pendapatnya sendiri, cita-cita serta nilai-nilai sendiri yang berbeda dengan orangtuanya. Hal ini dapat diketahui bahwa seorang remaja yang sedang mencari jati dirinya, sering bertindak semaunya dan labil mudah dipengaruhi oleh lingkungannya. Hal ini mengakibatkan rendahnya kesadaran beragama.

Kesadaran beragama adalah bagian integral dari aspek-aspek perkembangan remaja yang harus dikembangkan secara optimal, agar remaja memiliki landasan hidup yang kokoh, yaitu nilai-nilai moral, terutama yang bersumber dari agama, agar remaja memperoleh kematangan sistem moral yang membimbing perilakunya dalam kehidupan sehari-hari. Kesadaran beragama pada remaja dapat dilihat pada aspek ritual, 
Widia Wati, Silvianetri: Pengaruh Konseling Islam dalam Meningkatkan Kesadaran Sholat ...

di antaranya, melalui aktivitas sholat dalam kehidupan sehari-hari. Aktivitas sholat adalah bagian dari kesadaran beragama remaja. Hal ini ditegaskan Allah dalam firman-Nya, Orang-orang yang beriman kepada adanya kehidupan akhirat, tentu beriman kepada (Alqur'an, dan mereka selalu memelihara sholatnya.(Q.S Al-an'am: 92).

Ibadah sholat merupakan kewajiban bagi setiap umat Islam yang sudah baligh, sholat dapat dikerjakan sendiri-sendiri namun lebih dianjur untuk berjamaah. Pur (2011: 135) menjelaskan bahwa shalat berjamaah merupakan salah satu amalanamalan mustahab yang terpenting dan syiar Islam yang paling besar.

Penguatan kesadaran sholat berjemaah bagi remaja dibutuh suatu perlakuan, salah satu diantaranya melalui konseling Islam. Hallent (2002: 22) menjelaskan bahwa konseling Islami adalah suatu usaha membantu individu dalam menanggulangi penyimpangan perkembangan fitrah beragama yang dimilikinya, sehingga ia kembali menyadari peranannya sebagai khalifah dimuka bumi dan berfungsi untuk menyembah atau mengabdi kepada Allah SWT sehingga akhirnya tercipta kembali hubungan yang baik dengan Allah, dengan manusia dan alam semesta. Hal ini dapat dimaknai bahwa melalui konseling Islam secara klasikal dapat meningkatkan kesadaran beragama khususnya melaksanakan sholat berjamaah.

Sutoyo (2013: 207) mengatakan bahwa Hakikat bimbingan dan konseling Islami adalah upaya membantu individu belajar mengembangkan fitrah iman dan atau kembali kepada fitrah iman, dengan cara memberdayakan fitrah (jasmani, rohani, nafs, dan iman) mempelajari dan melaksanakan tuntutan Allah dan rasul-Nya, agar fitrahfitrah yang ada pada individu berkembang dan berfungsi dengan baik dan benar. Pada akhirnya diharapkan agar individu selamat dan memperoleh kebahagiaan yang sejati di dunia dan akhirat.

Pendapat di atas memperkuat asumsi jika diterapkan konseling Islam format klasikal dapat meningkatkan kesadaran sholat berjemaah remaja khususnya siswa di sekolah. Fenomena di sekolah menunjukkan kesadaran sholat berjamaah siswa sangat rendah.

Berdasarkan hasil wawancara dengan siswa tentang pandangannya terhadap sholat dzuhur berjamaah di sekolah, diperoleh data bahwa banyak yang beranggapan sholat dzuhur berjamaah itu sangat ribet, karena harus antri mengambil wudhu, rebut, sempit dalam mushola. Hasil wawancara dengan guru diperoleh data bahwa kesadaran siswa melakukan sholat dzuhur berjamaah sangat rendah, mereka sholat tidak dari hati. Fenomena ini menunjukkan rendahnya kesadaran siswa dalam melakukan sholat 
dzuhur berjamaah, hal ini mengindikasikan pentingnya diberikan treatment, salah satunya konseling Islam.

\section{Kesadaran Sholat Dzuhur Berjamaah}

Sholat merupakan kewajiban setiap Muslim yang ada di muka bumi ini, khusus di sekolah sholat yang di atur oleh peraturan sekolah ialah sholat dzuhur berjamaah, adapun yang dimaksud dengan sholat dzuhur berjamaah adalah sholat wajib 4 rakaat yang dilakukan di waktu siang hari secara bersama-sama yang dipimpin oleh seorang imam. Sholat berjamaah adalah sholat yang dilakukan secara bersama-sama dengan dipimpin oleh imam, sholat berjamaah ini setidaknya berjumlah dua orang, seorang bertindak sebagai imam dan lainya sebagai makmum (Amin, 2011: 72). Sementara itu menurut pengertian syarat, sholat berjamaah adalah adanya imam dan makmum dalam sholat (Muhaimin, 2013: 78). Sabiq (2008: 405) berpendapat bahwa sholat jamaah dapat dilakukan jika terdapat satu orang makmum dan satu orang imam, meskipun salah satunya adalah anak kecil atau perempuan.

Berdasarkan pendapat di atas dapat dimaknai bahwa sholat jamaah merupakan suatu ibadah yang sangat dianjurkan bagi setiap Muslim terutama sekali bagi kaum laki-laki. Sholat jamaah dapat dilakukan ketika ada seorang imam dan seorang makmum. Sholat jamaah adalah keterkaitan sholat imam dengan sholat makmumnya.

Menurut (Muhaimin, 2013: 53) sholat dzuhur terdiri dari empat rakaat, awal waktunya setelah matahari tergelincir dari pertengahan langit atau condong, dan akhir waktunya sampai dengan bayangan sesuatu di bawah matahari sama panjang dengan sesuatu tersebut.

Kesadaran berarti keadaan dimana seseorang mengerti, insaf dan tahu atas segala sesuatu yang berkaitan dengan dirinya. Secara bahasa, "kesadaran berasal dari kata dasar "sadar" yang mempunyai arti; insaf, yakin, merasa, tahu dan mengerti. Kesadaran berarti; keadaan tahu, mengerti dan merasa ataupun keinsafan. Arti kesadaran yang dimaksud adalah keadaan tahu, ingat dan merasa ataupun keinsafan atas dirinya sendiri kepada keadaan yang sebenarnya (Amin, 2004: 2-4). Menurut Wijaya (Anggreni, 2015: 19) menyatakan bahwa kesadaran adalah kehendak dan kesadaran hukum. Sadar diartikan merasa, tahu, ingat keadaan sebenarnya dan ingat keadaan dirinya. Kesadaran diartikan keadaan tahu, mengerti, dan merasa misalnya tentang harga diri, kehendak hukum dan lainnya. Menurut Soekanto (dalam Wardhani, 2008: 8).menyatakan bahwa terdapat empat indikator kesadaran yang masing-masing merupakan satu tahapan bagi tahapan berikutnya dan merujuk pada tingkat kesadaran tertentu mulai dari yang terendah 
sampai yang tertinggi yaitu pengetahuan, pemahaman, sikap, dan pola perilaku atau tindakan.

Berdasarkan pendapat di atas dapat dimaknai bahwa yang dimaksud dengan kesadaran yaitu seseorang dalam keadaan insaf, mengerti, tentang dirinya dan hukumhukum ataupun peraturan yang berlaku terhadap dirinya, termasuk peraturan dan perintah ajaran agama Islam yang mengatur segala perbuatan dalam kehidupannya yang harus dijalankannya dengan taat dan patuh.

\section{Konseling Islam Format Klasikal}

Konseling Islami adalah suatu usaha membantu individu dalam menanggulangi penyimpangan perkembangan fitrah beragama yang dimilikinya, sehingga ia kembali menyadari peranannya sebagai khalifah dimuka bumi dan berfungsi untuk menyembah atau mengabdi kepada Allah Swt sehingga akhirnya tercipta kembali hubungan yang baik dengan Allah, dengan manusia dan alam semesta (Hallent, 2002: 22). Lebih lanjut Az-Zahrani (dalam Fenti, 2015: 55) mengemukakan bahwa konseling Islami adalah memberikan arahan dan petunjuk bagi orang yang tersesat, baik arahan tersebut berupa pemikiran, orientasi kejiwaan, maupun etika dan penerapannya sesuai dan sejalan dengan sumber utama dan merupakan pedoman hidup Muslim, yakni Al-Quran dan sunah. Sedangkan menurut Tohari (1992: 5) konseling Islam adalah proses pemberian bantuan terhadap individu agar menyadari kembali eksistensinya sebagai makhluk Allah yang seharusnya hidup selaras dengan ketentuan dan petunjuk Allah, sehingga dapat mencapai kebahagiaan di dunia dan akhirat.

Sutoyo (2013: 207) mengatakan bahwa hakikat bimbingan dan konseling Islami adalah upaya membantu individu belajar mengembangkan fitrah iman dan atau kembali kepada fitrah iman, dengan cara memberdayakan (empowering) fitrah-fitrah (jasmani, rohani, nafs, dan iman) mempelajari dan melaksanakan tuntutan Allah dan rasul-Nya, agar fitrah-fitrah yang ada pada individu berkembang dan berfungsi dengan baik dan benar. Pada akhirnya diharapkan agar individu selamat dan memperoleh kebahagiaan yang sejati di dunia dan akhirat.

Berdasarkan paparan di atas dapat dilihat bahwa dengan pelaksanaan konseling Islami dapat mengembalikan manusia kepada fitrah imannya, fitrah iman ini sudah melekat pada diri manusia dari sejak lahir dan dikembangkan oleh diri sendiri dan oleh orang tua serta lingkungan. Agar fitrah iman itu berkembang dengan baik seseorang harus memahami segala suatu yang mempengaruhi iman tersebut. Salah satu yang mempengaruhi atau berkaitan dengan iman yaitu ibadah sholat termasuk sholat dzuhur berjamaah, untuk meningkatkan kesadaran sholat dzuhur berjamaah siswa dibutuhkan 
Widia Wati, Silvianetri: Pengaruh Konseling Islam dalam Meningkatkan Kesadaran Sholat ...

suatu metode konseling salah satunya dengan konseling Islam sebagaimana yang dikatakan oleh pendapat ahli di atas bahwa dengan konseling Islam ini dapat meningkatkan kesadaran siswa terhadap sholat berjamaah khususnya sholat dzuhur berjamaah di sekolah.

Konseling Islam yang dimaksud di sini yaitu konseling Islam format klasikal. Format klasikal yaitu suatu layanan Bimbingan dan Konseling yang dilaksanakan di dalam kelas, sebagaimana yang dikatakan oleh Nurihsan (2013:34) yang mana pengertian bimbingan klasikal yaitu layanan dasar bimbingan untuk membantu seluruh peserta didik dalam mengembangkan perilaku efektif dan keterampilan hidupnya yang mengacu kepada tugas perkembangan peserta didik, layanan ini ditujukan untuk seluruh peserta didik. Selanjutnya Gazda (dalam Mastur dan Triyono, 2014: 2) menyatakan bimbingan klasikal merupakan suatu bimbingan yang digunakan untuk mencegah masalah-masalah perkembangan, meliputi: informasi pendidikan, pekerjaan, personal, dan sosial dilaksanakan dalam bentuk pengajaran yang sistematis dalam suatu ruang kelas yang berisi antara 20-25 siswa dengan tujuan untuk meningkatkan pemahaman diri dan orang lain serta perubahan sikap dengan menggunakan berbagai media dan dinamika kelompok.

Berdasarkan paparan di atas dapat dipahami bahwa layanan klasikal merupakan suatu layanan dasar yang memberikan bimbingan kepada sejumlah yang tergabung dalam satu kegiatan pembelajaran untuk membantu peserta didik mengembangkan prilaku efektif dalam rangka mencapai tugas perkembangannya. Jadi peneliti melaksanakan konseling Islam format klasikal untuk meningkatkan kesadaran siswa dalam melakukan sholat dzuhur berjamaah di sekolah. Konseling Islam ini jika dilaksanakan dengan baik dan efektif akan memberikan dampak kepada peningkatan kesadaran diri siswa dalam melaksanakan sholat dzuhur berjamaah di sekolah.

\section{METODE}

Metode yang digunakan dalam penelitian ini yaitu eksperimen dengan jenis design pre eksperimen tipe one group pretest-post test design. Sugiyono (2013: 74) menjelaskan pada one group pretest and posttest design adalah terdapat pretest sebelum diberikan perlakukan, dengan demikian hasil perlakukan dapat diketahui lebih akurat, karena membandingkan keadaan sebelum dan sesudah perlakuan.

Populasi penelitian ini yaitu siswa SMAN 1 Pasaman yang memiliki kesadaran sholat dzuhur berjamaahnya rendah. Sampel diambil dengan menggunakan teknik random sampling agar anggota populasi mempunyai kesempatan yang sama menjadi anggota sampel, tidak ada diskriminasi terhadap 
anggota populasi. Sampel penelitian sebanyak 25 orang. Teknik pengumpulan data menggunakan skala yang terkait dengan kesadaran sholat dzuhur berjamaah. Adapun bentuk analisis data dalam penelitian ini menggunakan uji-t.

\section{PEMBAHASAN}

Hasil penelitian terkait dengan data kesadaran sholat dzuhur berjamaah siswa SMAN 1 Pasaman. Data tersebut dianalisis, yang mana dilakukan dua kali pengukuran yaitu pretest. Pretest dilakukan sebelum diberikan treatment. Selanjutnya sesudah diberikan treatment dilakukan posttest.

Setelah dilakukan pretest kemudian dilakukan treatment sebanyak 6 kali, dengan materi tentang hakikat sholat berjamaah, syarat, tata cara pelaksanaannya, dan fungsinya, keutamaan, dan anjuran sholat berjamaah dengan menggunakan layanan konseling Islam format klasikal.

Setelah dilakukan treatment, kemudian dilakukan kembali pengukuran atau posttest, pengukuran pada posttest menunjukkan bahwa skor siswa sebanyak 1469 dengan rata-rata 58,76, yang mana berada pada kategori tinggi. Hal ini menunjukkan bahwa telah terjadi perbedaan skor sebanyak 318 poin, dengan rata-rata perbedaan skor 12.72 sebelum dan sesudah diberikan treatment. Artinya layanan konseling Islam format klasikal dapat meningkatkan kesadaran sholat dzuhur berjamaah siswa di sekolah.
Analisis data menggunakan uji-t atau uji beda. Sebelum melakukan uji-t atau uji beda terlebih dahulu melakukan uji prasyarat yaitu uji normalitas dan homogenitas untuk melihat data berdistribusi normal dan homogen. Pada uji normalitas didapatkan hasil yaitu $0.546>0.05$. artinya variabel tersebut memiliki distribusi data yang normal. Selanjutnya uji homogenitas didapatkan $0.217>0.05$ artinya data variabel kesadaran sholat dzuhur berjamaah bersifat homogen. Selanjutnya peneliti melakukan uji-t atau uji beda dengan hasil $t_{o} 15>2,821$ pada $\mathrm{df}=23$, taraf signifikansi $1 \%$. Ini berarti bahwa layanan konseling Islam format klasikal berpengaruh signifikan untuk meningkatkan kesadaran sholat dzuhur berjamaah siswa.

Berdasarkan hasil analisis data empirik penelitian terungkap bahwa terdapat pengaruh yang signifikan antara konseling Islam format klasikal dengan peningkatan kesadaran sholat dzuhur berjamaah siswa. Artinya data empirik ini mendukung teori Az-Zahrani (dalam Fenti, (2015: 55) yang mengemukakan bahwa konseling Islami yaitu memberikan arahan dan petunjuk bagi orang yang tersesat, baik arahan tersebut berupa pemikiran, orientasi kejiwaan, maupun etika dan penerapannya sesuai dan sejalan dengan sumber utama dan merupakan pedoman hidup Muslim, yakni Al-Quran dan sunah. Selanjutnya Musnamar (1992: 5) menyatakan bahwa konseling Islam adalah 
proses pemberian bantuan terhadap individu agar menyadari kembali eksistensinya sebagai makhluk Allah yang seharusnya hidup selaras dengan ketentuan dan petunjuk Allah, sehingga dapat mencapai kebahagiaan di dunia dan akhirat.

Paparan di atas terlihat bahwa konseling Islam dapat meningkatkan kesadaran untuk melaksanakan tuntutan Allah dan rasul-Nya yang salah satu anjuran Rasul ialah sholat berjamaah, dalam hal ini penulis berupaya melihat pengaruh konseling Islam terhadap peningkatan kesadaran sholat dzuhur berjamaah dengan harapan dapat membantu siswa yang awalnya kesadaran untuk sholat dzuhur berjamaah sangat rendah sehingga memiliki kesadaran yang tinggi untuk melakukan sholat dzuhur berjamaah.

Penanganan yang peneliti lakukan dalam meningkatkan kesadaran sholat dzuhur berjamaah siswa dengan menggunakan konseling Islam format klasikal. Saat peneliti melakukan treatment anggota kelas merespon dengan baik apa yang peneliti sampaikan. Dinamika kelas terbangun dengan baik terbukti semua siswa berpartisipasi aktif baik itu dalam bertanya, menjawab, dan menjelaskan kepada temanteman mereka, serta menanggapi setiap vidio yang ditampilkan dan mampu mengambil pelajaran dari apa yang dilihat, didengar, disimak, sehingga materi yang peneliti sampaikan benar-benar mereka pahami dengan baik, ditambah lagi peneliti memberikan contoh-contoh yang ada dalam kehidupan sehari-hari ganjaran apa yang didapatkan jika melakukan ini serta peneliti juga memberikan video-video berkaitan dengan materi yang sedang dibahas. Artinya treatment yang di berikan sebanyak enam kali ini dapat meningkatkan kesadaran siswa dalam melakukan sholat dzuhur berjamaah

Jika konseling Islam format klasikal dilakukan oleh guru BK di sekolah akan mampu meningkatkan kesadaran sholat dzuhur berjamaah siswa. Jika ini tidak dilakukan tentu kesadaran sholat dzuhur berjamaah siswa akan tetap rendah, hal ini mengindikasikan bahwa konseling Islam format klasikal memiliki peran yang sangat penting dalam meningkatkan kesadaran sholat dzuhur berjamaah siswa. Artinya guru BK tentu harus menerapkan konseling Islam format klasikal agar meningkatnya kesadaran sholat dzuhur berjamaah siswa.

Fenomena yang terjadi konseling Islam format klasikal ini belum pernah dilaksanakan atau tidak berjalan dengan baik di sekolah wajar saja kesadaran siswa untuk melakukan sholat berjamaah rendah, justru itu pada guru BK semestinya perlu menerapkan konseling Islam format klasikal untuk meningkatkan kesadaran sholat dzuhur berjamaah siswa.

\section{KESIMPULAN}

Kesimpulan penelitian tentang peningkatan kesadaran siswa untuk sholat 
berjamaah melalui Konseling Islam, yaitu:

(1) adanya peningkatan kesadaran sholat dzuhur berjamaah siswa setelah diberikan treatment Konseling Islam format klasikal, (2) terdapat pengaruh signifikan Konseling Islam format klasikal dalam meningkatkan pemahaman siswa terhadap sholat dzuhur berjamaah dengan nilai $t_{\mathrm{o}} 15>\mathrm{t}_{\mathrm{t}} 2,80$.

Berdasarkan kesimpulan penelitian di atas, ada beberapa saran terkait dengan penelitian tersebut, yaitu: (1) Guru Bimbingan dan Konseling di sekolah dapat menggunakan Konseling Islam format klasikal untuk mengentaskan masalah siswa terkait kurangnya kesadaran untuk sholat berjamaah, (2) Praktisi Bimbingan dan Konseling dapat menggunakan Konseling Islam format klasikal untuk meningkatkan kesadaran dalam meningkatkan kesadaran sholat berjamaah, dan (3) Peneliti selanjutnya dapat menggunakan Konseling Islam format klasikal untuk meningkatkan kesadaran pada aspek positif lainnya dalam kehidupan.

\section{DAFTARPUSTAKA}

Amin. (2004). Kesadaran Beragama. Online. (diakses, 1 Juni 2018) Retrieved from //jtptiain-gdl-s1-2004-aminshofwa714-BAB2_319-5.pdf

Arifin, B. S. (2008). Psikologi Agama. Bandung: Pustaka Setia.

Daryono. (2008). Evaluasi Pendidikan, Rineka Cipta. Jakarta: Jakarta Pusat Press. Jakarta.

Ebaugh, H. R. (2006). Handbook of Religion and Social Institutions. Texas: Springer.
Haq, R. K. (2015). Hubungan sholat berjamaah dengan tingkat depresi pada lansia dipanti Sosial Tresna Werdha (PSTW) budi mulia margaguna Jakarta Selatan. Skripsi. Jakarta: UIN Syarif Hidayatullah.

Hikmawati. F. (2015). Bimbingan Dan Konseling Perspektif Islam. Jakarta: PT Raja Grafindo.

Mastur \& Triyono. (2014). Materi Layanan Klasikal Bimbingan dan Konseling Bidang Bimbingan Karier. Yogyakarta: Paramitra Publishing.

Muhaimin, A. (2013). Tuntutan Shalat Fardhu Dan Sunnah. Jogyakarta: Darul Hikmah.

Musnamar, T. (1992). Dasar- dasar Bimbingan \& Konseling Islam. Yogyakarta: UII Press.

Nurihsan, A. J. (2010). Strategi Layanan Bimbingan \& Konselsing. Bandung: PT. Refika Aditama.

Sudijono, A. (2011). Pengantar Evaluasi Pendidikan. PT Raja Grafindo Persada. Jakarta.

Sardiman. (2007). Interaksi dan Motivasi Belajar Mengajar. Jakarta: PT Raja Grafindo Persada.

Sugiyono. (2013). Metode penelitian kualitatif kuantitatif dan $R \quad \& \quad D$. Bandung: Alfabeta.

Sutoyo, A. (2013). Bimbingandan Konseling Islami (Teori Dan Pratik). Yogyakarta: Pustaka Pelajar.

Sujanto, A. (1996). Psikologi Perkembangan. Jakarta: PT.Rineka Cipta.

Supranto. (2007). Teknik Sampling untuk Survey dan Eksperimen. Jakarta: PT. Rineka. Cipta.

Wardhani S. H. (2008). Studi tentang kesadaran. Retrived from http: http://lontar.ui.ac.id/file?file=digital/12279 5-S-5345-studi\%20 tentang-Literatur.pdf 